\title{
Climate change and plant distribution: local models predict high-elevation persistence
}

\author{
CHRISTOPHE F. RANDIN*, ROBIN ENGLER*, SIGNE NORMAND†, MASSIMILIANO \\ ZAPPA $\ddagger$ NIKLAUS E. ZIMMERMANN \\ WILFRIED THUILLER and ANTOINE GUISAN* \\ ${ }^{*}$ Laboratory for Conservation Biology, Department of Ecology and Evolution, Biophore, CH-1015 Lausanne, Switzerland, \\ $\dagger$ Department of Biological Sciences, University of Aarhus, Ny Munkegade, Building 1540, DK-8000 Aarhus C, Denmark, $\ddagger$ Swiss \\ Federal Research Institute WSL, Land Use Dynamics, Zuercherstrasse 111, CH-8903 Birmensdorf, Switzerland, §Faculté des \\ Géosciences et de l'Environnement (GSE), University of Lausanne, CH-1015 Lausanne, Switzerland, -Laboratoire d'Ecologie \\ Alpine, UMR CNRS 5553, Université Joseph Fourier, BP 53, 38041 Grenoble Cedex 9, France
}

\begin{abstract}
Mountain ecosystems will likely be affected by global warming during the 21st century, with substantial biodiversity loss predicted by species distribution models (SDMs). Depending on the geographic extent, elevation range, and spatial resolution of data used in making these models, different rates of habitat loss have been predicted, with associated risk of species extinction. Few coordinated across-scale comparisons have been made using data of different resolutions and geographic extents. Here, we assess whether climate change-induced habitat losses predicted at the European scale $\left(10 \times 10^{\prime}\right.$ grid cells) are also predicted from local-scale data and modeling ( $25 \mathrm{~m} \times 25 \mathrm{~m}$ grid cells) in two regions of the Swiss Alps. We show that local-scale models predict persistence of suitable habitats in up to $100 \%$ of species that were predicted by a European-scale model to lose all their suitable habitats in the area. Proportion of habitat loss depends on climate change scenario and study area. We find good agreement between the mismatch in predictions between scales and the fine-grain elevation range within $10 \times 10^{\prime}$ cells. The greatest prediction discrepancy for alpine species occurs in the area with the largest nival zone. Our results suggest elevation range as the main driver for the observed prediction discrepancies. Local-scale projections may better reflect the possibility for species to track their climatic requirement toward higher elevations.
\end{abstract}

Keywords: climate change, Europe, mountain region, species distribution model, Swiss Alps

Received 19 June 2008 and accepted 8 September 2008

\section{Introduction}

Mountain ecosystems are likely sensitive to global warming owing to the reduction in area with increasing elevation (Guisan et al., 1995; Theurillat et al., 1998; Diaz et al., 2003; Beniston, 2006). A recent global assessment of the impacts of climate change on these ecosystems suggests that they should experience unprecedented rates of warming during the 21st century, two to three times greater than observed during the 20th century (Nogués-Bravo et al., 2006). These rapid changes in temperature and other climate parameters at high elevations are expected to have strong effects on plant

Correspondence: Antoine Guisan, tel. + 4121692 42 54, fax + 41 2169242 65, e-mail: antoine.guisan@unil.ch communities (Guisan et al., 1995; Beniston et al., 1996; Guisan \& Theurillat, 2000; Walther, 2003). The first biological impacts of past and ongoing global warming are already visible in the Alps, and include the upward shift of treelines (Gehrig-Fasel, 2007) and the upward shift and range reduction in alpine and nival plant species (Braun-Blanquet, 1957; Hofer, 1992; Grabherr et al., 1994; Pauli et al., 1996, 2007; Walther et al., 2005; Vittoz et al., 2006).

In the last decade, species distribution models (SDMs; Guisan \& Zimmermann, 2000; Guisan \& Thuiller, 2005) have become important tools to evaluate the potential impacts of climate change on plant distributions (Bakkenes et al., 2002; Thomas et al., 2004; Thuiller et al., 2005). These tools statistically relate multiple abiotic habitat characteristics (sensu Kearney \& Porter, 2004) 
with observed occurrences of a species, thus fitting the original definition of the Hutchinsonian (Hutchinson, 1957) environmental niche (Kearney \& Porter, 2004; i.e. without explicitly requiring a mechanistic link between environmental gradients and population fitness (see also Guisan \& Thuiller, 2005; Araujo \& Guisan, 2006). Hereafter, we will simply refer to the realized niche for this initial definition of the niche.

Using these tools, models of climate change impacts on biodiversity have been developed at several scales (but see Davis et al., 1998; Bahn \& Körner, 2003; Hampe, 2004; Dormann, 2007). At the extent of western Europe, Thuiller et al. (2005) forecasted that the plant diversity of some European mountain ranges (e.g. mid-elevation Alps) could be disproportionably sensitive to climate change, with up to $60 \%$ species loss per $10^{\prime}$ grid cell. This study modeled the distribution of 1350 species using data from the Atlas Florae Europaeae (AFE; Lahti \& Lampinen, 1999). Similarly, a local-scale study of 85 subalpine and alpine nonwoody plants of open habitat was conducted at high resolution $(20 \mathrm{~m} \times 20 \mathrm{~m})$ in the Austrian Alps (Dirnböck et al., 2003). The authors predicted that up to $40-50 \%$ of the plant species could potentially become extinct owing to climate change. Finally, in a study of 62 alpine and nival plants, Guisan \& Theurillat (2000) predicted relatively low rates of total habitat loss, between $2 \%$ and $5 \%$, but nearly $40 \%$ of the species were nevertheless predicted to lose more than $90 \%$ of their suitable habitat. These SDM results suggest that alpine and nival plants, in particular, may lose much of their suitable climatic habitats, owing to the decrease in suitable habitat area with increasing elevation (Guisan \& Theurillat, 2000). Nonetheless, still few studies have used SDMs to assess the possible impacts of climate change on plant species in mountain environments (e.g. Dirnböck et al., 2003).

Although SDM studies consistently predict substantial impacts on plant diversity in mountains, the rates of predicted habitat loss vary among studies, which themselves vary in study area extent, data resolution, and species composition. In spite of this and of variation in the results of the studies, very few comparisons of predictions across resolutions in a single region have been attempted (e.g. Trivedi et al., 2008). This is potentially an important deficiency because coarse-resolution predictions based on SDMs are commonly used in the preparation of reports by the Intergovernmental Panel on Climate Change (IPCC; http://www.ipcc.ch). These reports are then of potential use to conservation planners, managers, and other decision makers to anticipate biodiversity losses in alpine and other systems across local, regional, and larger scales. Thus, an assessment is needed as to whether studies conducted at different scales yield comparable and consistent predictions.
A particular aspect that needs to be assessed is whether studies conducted at different spatial resolutions in a common study area and pool of species lead to different predictions of climate impacts. Such a discrepancy might, for instance, arise because different resolutions can reflect and represent topography, habitat, and climate variation differently. The relationship between certain environmental variables and species occurrence can differ when calculated at local or European scales (Guisan \& Thuiller, 2005). For example, the mean temperature interpolated from local stations at a $20 \mathrm{~m}$ resolution (Dirnböck et al., 2003) contains more variability than expressed by the mean temperature within a $50 \mathrm{~km} \times 50 \mathrm{~km}$ grid cell in which variation in elevation is poorly represented (Thuiller et al., 2005). Such differences in resolution and study area size might produce differences among SDMs in regard to the estimated minimal annual temperature tolerated by a species. This could happen when models are fitted with temperature data coming from relatively large cell sizes over a large area (e.g. Europe) that do not represent well substantial temperature variation with elevation. This, in turn, could result in underprediction of species distributions in areas at the cold end of the temperature gradient. In contrast, models fitted at a local scale and fine resolution could predict the persistence of suitable thermal habitat at high elevations within coarser resolution cells predicted overall to be unsuitable from models fitted at larger scale (e.g. from Thuiller et al., 2005).

Here, we examine this 'local high-elevation habitat persistence hypothesis.' We estimate, with fine-resolution (local-scale) models, the proportion of suitable habitat remaining for each species after climate change within cells predicted by coarse-resolution (Europeanscale) models to become overall unsuitable. We further investigate whether such predicted local habitat persistence results from (1) the particular topographic configuration in the local study areas; (2) the differences in estimated climatic niche of species when measured at both scales by determining whether the curves of probability of species presence along climatic gradients are truncated when fitted with local-scale data; (3) the choice of modeling techniques; and (4) difference in performance of models that are fitted under current conditions using data at the two extents and resolutions.

\section{Methods}

\section{Study areas}

We fitted SDMs for Western Europe $\left(34^{\circ} \mathrm{N}-72^{\circ} \mathrm{N}, 11^{\circ} \mathrm{W}-\right.$ $32^{\circ} \mathrm{E} ; 5.7 \times 10^{6} \mathrm{~km}^{2}$ ) and for two local study areas in the 


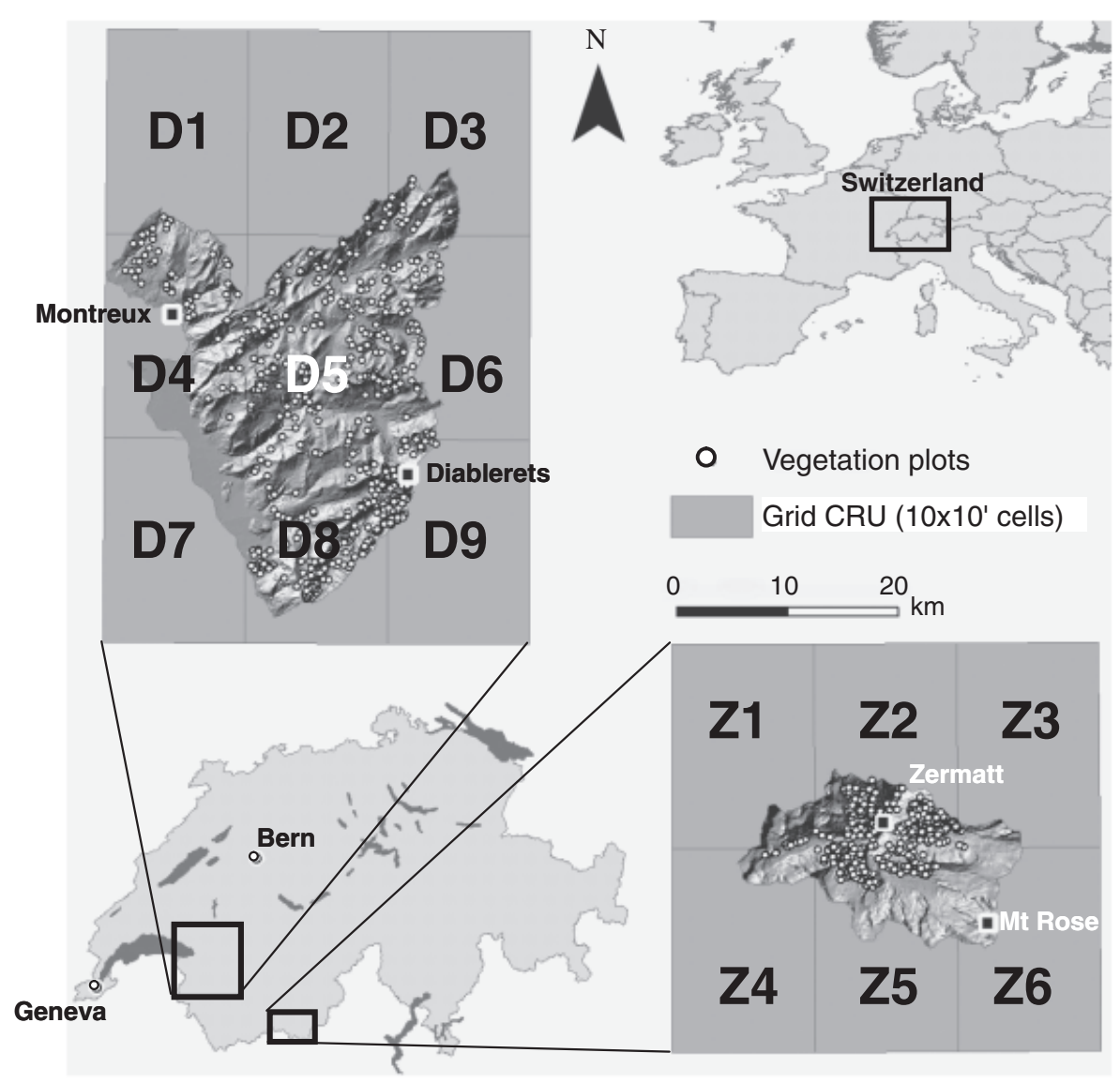

Fig. 1 Location of the Diablerets and Zermatt study areas. $10 \times 10^{\prime}$ pixels used for projections at the European scale are indicated for each study area.

Western Alps: Diablerets and Zermatt (Fig. 1). The Diablerets study area (Fig. 1) covers nearly all mountain massifs of the Western Alps of the Canton de Vaud (Swiss state, $6^{\circ} 50^{\prime}-7^{\circ} 10^{\prime} \mathrm{E}, 46^{\circ} 10^{\prime}-46^{\circ} 30^{\prime} \mathrm{N},>700 \mathrm{~km}^{2}$ ). The elevation ranges from $375 \mathrm{~m}$ in Montreux to $3210 \mathrm{~m}$ on the top of the Diablerets massif. The annual mean temperature and total precipitation vary, respectively, from $8{ }^{\circ} \mathrm{C}$ and $1200 \mathrm{~mm}$ at $600 \mathrm{~m}$ elevation to $-5^{\circ} \mathrm{C}$ and $2600 \mathrm{~mm}$ at $3000 \mathrm{~m}$ elevation (Bouët, 1985).

The Zermatt study area is located in the Central Alps of the Canton of Valais (Switzerland; $7^{\circ} 58^{\prime}-7^{\circ} 91^{\prime} \mathrm{E}$, $45^{\circ} 92^{\prime}-46^{\circ} 06^{\prime} \mathrm{N}, 243 \mathrm{~km}^{2}$ ) at the end of the Matter valley. Its elevation varies from $1480 \mathrm{~m}$ at the bottom of the valley near the village of Zermatt to $4634 \mathrm{~m}$ on the top of the Mt Rose massif. The climate conditions in the Matter valley have a continental character with low precipitation and high-radiation budgets. The annual mean temperature and total precipitation range, respectively, from $3.5^{\circ} \mathrm{C}$ and $612 \mathrm{~mm}$ at $1638 \mathrm{~m}$ elevation to $-6.5^{\circ} \mathrm{C}$ and $680 \mathrm{~mm}$ at $3130 \mathrm{~m}$ elevation (MeteoSwiss). This area also holds glaciers that currently comprise $43 \%$ of the study area.

\section{Species data}

Data on the distributions of species in Europe were extracted from the AFE (Lahti \& Lampinen, 1999), which uses a mapping grid of $50 \mathrm{~km} \times 50 \mathrm{~km}$ cells (hereafter called 'AFE cells') based on the Universal Transverse Mercator (UTM) projection and the Military Grid Reference. Our sample included 2089 AFE cells. Species distributions data at the local scale were based on $55064 \mathrm{~m}^{2}$ vegetation plots in the Diablerets area and 1511 vegetation plots between 10 and $30 \mathrm{~m}^{2}$ in the Zermatt area. Plots were restricted to open nonwoody vegetation (grassland, meadow, rock, and scree vegetation).

We developed models for 78 species that occur in more than 19 AFE cells and in at least one of the two local study areas. Of these species, 42 occur in the Diablerets and 51 in Zermatt (see Supporting information Appendix S1).

\section{Climatic predictors}

We used seven climatically derived variables expected to have a major direct ecophysiological impact on plant 
species (see Prentice et al., 1992 for examples of variables; see Körner, 2003 for autoecology of alpine plants): growing degree days (GDD $>5^{\circ} \mathrm{C}$ ), mean annual temperature, minimum temperature of the coldest month, mean annual, winter and summer precipitation, and potential evapotranspiration. For the European scale, these climatic variables were obtained from the Climatic Research Unit (http://www.cru.uea.ac.uk) at a $10^{\prime}$ resolution. Mean values were averaged for the standard period 1961-1990. These $10 \times 10^{\prime}$ maps were then aggregated to $50 \mathrm{~km} \times 50 \mathrm{~km}$ resolution to match the AFE species data and allow fitting the models, which were then projected back on the $10 \times 10^{\prime}$ maps. The Diablerets and the Zermatt study areas were captured by nine and six $10 \times 10^{\prime}$ cells, respectively (Fig. 1 ).

We generated an identical set of environmental predictors for the Diablerets and Zermatt study areas at a local-scale resolution of $25 \mathrm{~m}$ (hereafter called ' $25 \mathrm{~m} \times 25 \mathrm{~m}$ cells'). We first calculated linear lapse rates (i.e. rate of change along elevation) for long-term (19611990) monthly mean temperature and monthly rainfall taken from the national meteorological networks of Switzerland (MeteoSwiss). Next, we normalized the monthly values to sea level ( $0 \mathrm{~m}$ a.s.l.), using the regression lapse rates fitted along the elevation gradient, and interpolated the $0 \mathrm{~m}$ data to the whole surface of both study areas using inverse distance weighted interpolations (IDW). Finally, the spatially interpolated values (representing locally adjusted regression intercepts) were re-projected to actual elevations using a $25 \mathrm{~m}$ DEM (Digital Elevation Model) and the regression lapse rates (for details, see Zimmermann \& Kienast, 1999). Additionally, the spatially distributed hydrological model PREVAH (Gurtz et al., 1999; Randin et al., 2006) was used to obtain a physically based predictor for potential evapotranspiration in both study areas, taking into account the effect of local topography.

\section{Climate change scenarios}

Spatial climate change projections were derived on the European scale for the 2080 time period $\left(10 \times 10^{\prime}\right.$ climatic grids; averages for 2070-2099) from the general circulation model (GCM) provided by the UK Hadley Center for Climate Prediction and Research (HadCM3; Carson, 1999), for which output from four different socioeconomic storylines (A1FI, A2, B1, B2) provided by the IPCC (Nakicenovic \& Swart, 2000) were available. With an average increase of $+6.3 \pm 0.3^{\circ} \mathrm{C}$ in the two study areas for the period 2070-2099, the A1FI climate change scenario is the most extreme. $\mathrm{B} 1$ is mildest $\left(+3.2 \pm 0.2^{\circ} \mathrm{C}\right)$, and $\mathrm{A} 2\left(+4.9 \pm 0.3^{\circ} \mathrm{C}\right)$ and $\mathrm{B} 2\left(+3.5 \pm 0.2^{\circ} \mathrm{C}\right)$ are intermediate.
Climate change projections at the local scale were obtained for temperature and precipitation and the four IPCC scenarios by calculating monthly mean anomalies between the standard period 1961-1990 and the future time period $2070-2099$ based on the $10 \times 10^{\prime}$ climate grids. These anomalies were then downscaled to the $25 \mathrm{~m}$ resolution of local models using bilinear interpolation and added to the local-scale climatic predictors.

\section{SDMs and their projections}

We calibrated and projected SDMs (Guisan \& Zimmermann, 2000; Guisan \& Thuiller, 2005) at both European and local scales using the latest version of the BIOMOD package (Thuiller, 2003), so as to follow as closely as possible the methods of Thuiller et al. (2005). For each species, generalized linear models (GLM), generalized additive models (GAM), and gradient boosting machine (GBM) were calibrated on a random sample of $70 \%$ of the initial observation data and evaluated on the remaining 30\% dataset (but see Araujo et al., 2005b) using the area under the curve (AUC) of a receiver operating characteristic (ROC) plot (Fielding \& Bell, 1997). We selected for each species and each scale the modeling technique that gives the best AUC value [best modeling technique approach - see Thuiller (2003)].

The most commonly used models for predicting species distribution so far are GLMs (e.g. Hill \& Caswell, 1999; Bakkenes et al., 2002; Guisan et al., 2002) and GAMs are increasingly used (Yee \& Mitchell, 1991; Frescino et al., 2001; Guisan et al., 2002; Thuiller et al., 2006a), whereas GBM (Friedman et al., 2000) has only recently been used (Leathwick et al., 2006; Broennimann et al., 2007; Pearman et al., 2008) and implemented in BIOMOD (Leathwick et al., 2006; Thuiller et al., 2006b). GBM was ranked as the best performing techniques in a recent large comparative analysis by Elith et al. (2006).

Models for 78 species were fitted at the European scale using the AFE distribution data at a resolution of $50 \mathrm{~km} \times 50 \mathrm{~km}$. These models were then used to predict current and future species' occurrence within the $10 \times 10^{\prime}$ cells overlaying the two study areas, following the procedure proposed by Araujo et al. (2005a). Although we agree that this downscaling procedure can generate additional uncertainty, and thus should be used with caution, we used it for sake of comparability with previous studies at the European scale. At the local scale, models were fitted and species distributions were predicted for 42 species in the Diablerets and for 51 species in Zermatt using the $25 \mathrm{~m} \times 25 \mathrm{~m}$ resolution climatic maps of the two study areas. Masks based on forests, lakes, urbanized areas, roads, and rivers were subsequently applied at the local scale to avoid spurious projections at locations that were not suitable 
for reasons other than climate. Finally, species predictions were further restricted to landcover categories (grassland, meadow rock, and scree) on which the species was at least observed once.

For each species, we derived presence-absence predictions by using a threshold probability of presence that maximized the percentage of presences and absences correctly predicted in the training dataset (Pearce \& Ferrier, 2000; Thuiller, 2003).

\section{Calculating the persistence rate at local scale}

A species would likely become extinct when predicted to lose $100 \%$ of its suitable habitat. However, because the link between habitat loss and extinction formally requires a population viability analysis (PVA) in addition to predictions of the spatial distribution of habitat (Botkin et al., 2007), we only discuss here our projections in terms of habitat loss. Four situations are possible when comparing predicted habitat suitability under current and future climatic conditions at the two scales (i.e. the four cells of a two-way contingency table). First, a $10 \times 10^{\prime}$ cell might be suitable under the Europeanscale model and also contains suitable $25 \mathrm{~m} \times 25 \mathrm{~m}$ cells predicted by the local model. Second, a $10 \times 10^{\prime}$ cell might be predicted suitable but have no suitable $25 \mathrm{~m} \times 25 \mathrm{~m}$ cell predicted within it. Third, a $10 \times 10^{\prime}$ cell might be predicted unsuitable but one or more $25 \mathrm{~m} \times 25 \mathrm{~m}$ cells are predicted suitable within it. Finally, a $10 \times 10^{\prime}$ cell might be predicted unsuitable and does not contain any suitable $25 \mathrm{~m} \times 25 \mathrm{~m}$ cells. Cases 2 and 3 represent mismatch in the modeling outcome at the two scales. Furthermore, loss of suitable habitat only occurs when a cell predicted suitable under current climate becomes unsuitable after climate change. Because our study areas only partially overlap with each $10 \times 10^{\prime}$ cell, we can only quantify the third case here, allowing us to test the local scale 'refugia' hypothesis.

We examine how frequently local persistence is predicted to occur by calculating a coefficient across the $s$ species predicted to be extinct within the $10 \times 10^{\prime}$ cells. Let $l_{i}$ be the total number of $10 \times 10^{\prime}$ cells predicted to become unsuitable in the future for species $i$ by the European model. Let then $p_{i}$ be the number of times the local model predicts the persistence of at least one suitable $25 \mathrm{~m} \times 25 \mathrm{~m}$ cell for species $i$ among the $l_{i} 10 \times 10^{\prime}$ cells. We calculated a local persistence coefficient $P$ within each $10 \times 10^{\prime}$ cell considered (cell-specific $P$ ) or for each of the $s$ species separately considering all the $10 \times 10^{\prime}$ cells they occurred initially (species-specific $P$ ) as follows:

$$
P=\frac{\sum_{i=1}^{s} p_{i}}{\sum_{i=1}^{s} l_{i}} .
$$

The local persistence coefficient reaches a maximum value of 100 when all species within the $10 \times 10^{\prime}$ cells are predicted by local models to have sufficient habitat to persist.

\section{Sensitivity analysis of the $\mathrm{P}$ coefficient}

In order to discuss the potential errors generated by considering a minimum of 1 pixel in the $P$ coefficient (e.g. the pixel may be a false-positive), $P$ was calculated for a set of different minimum numbers of $25 \mathrm{~m} \times 25 \mathrm{~m}$ cells with suitable habitat remaining $(1,10,50,100,200$, 500, 1000, and $200025 \mathrm{~m} \times 25 \mathrm{~m}$ cells).

\section{Possible causes of habitat persistence at the local scale}

We calculated several metrics to assess reasons for possible habitat persistence at the local scale. Predicted local persistence could result from differences in the elevation ranges represented in $10 \times 10^{\prime}$ cells or from the divergence between the estimates of climatic conditions at the two scales. In the first step, we examined the temperature distribution of the $25 \mathrm{~m} \times 25 \mathrm{~m}$ cells within each $10 \times 10^{\prime}$ cell. We then controlled whether a relationship existed between the persistence coefficient and (i) the percent overlay between the study area and the $10 \times 10^{\prime}$ cells and (ii) the minimum, mean, maximum elevation, and range of elevation of $25 \mathrm{~m} \times 25 \mathrm{~m}$ cells within the $10 \times 10^{\prime}$ cell and study area (i.e. the intersection). In the second step, we measured for each $10 \times 10^{\prime}$ cell the agreement between the estimates of mean annual temperature and precipitation based on the low- and high-resolution climatic data available at the European and local scales, respectively. For this set of analysis, $P$ was calculated separately for each $10 \times 10^{\prime}$ cell by pooling the species (cell-specific $P$ ). For all following analyses, $P$ was calculated separately for each species predicted extinct within the $10 \times 10^{\prime}$ cells by pooling the $10 \times 10^{\prime}$ cells (species-specific $P$ ).

Local persistence of habitat may also result from differences in species' elevation optimum, as high-elevation species mostly are expected to be negatively affected by climate change. To test this, we derived an index of elevation optimum for the 78 species as follows. A species was first assigned one of three possible values for its association (VA) with each elevation belt (EB from low to high: $1=$ colline, $2=$ montane, $3=$ subalpine, $4=$ alpine, $5=$ nival), based on data from the Atlas Flora Alpina (Aeschimann et al., 2005). Values for VA are as follows: 0 if absent, 1 if not frequent, and 2 if commonly present within the corresponding elevation belt. The elevation optimum index was then calculated as

$$
\text { Index }=\sum \frac{\mathrm{EB} \times \mathrm{VA}}{\sum \mathrm{VA}} .
$$


It resulted in four categories: $1<$ montane $\leq 2$; $2<$ subalpine $\leq 3 ; 3<$ alpine $\leq 4 ; 4<$ nival $\leq 5$. Because of the low number of nival species, these species were pooled with alpine species. We then examined the frequency with which species habitat persisted within each of these categories.

Likewise, local habitat persistence could depend on the position of species' optimum along climatic gradients. We therefore calculated the position of the environmental optimum of each species at both scales. Training data were concatenated, centered, and scaled for the seven climatic variables, so that the multidimensional space defined by the environmental variables was the same at the two scales. Finally, a principal component analysis (PCA) was applied to the difference between the centroids of the species' position at local and European scales (Pearman et al., 2008). The relationship between this difference and the persistence coefficient was tested with linear regressions under the four climate change scenarios.

Furthermore, truncated response curves may result in spurious future predictions of species' distributions (Thuiller et al., 2004). Therefore, we estimated the number of species with truncated response curves at local and European scales using Huisman-Olff-Fresco models (HOF models; Huisman et al., 1993; Oksanen \& Minchin, 2002). HOF models include a hierarchical set of five models of increasing complexity: (I) flat curve with no response, (II) monotone increasing curve, (III) monotone increasing curve reaching a 'plateau,' (IV) symmetric unimodal curve, and (V) skewed unimodal response curve. Models I-III represent truncated responses, while models VI-V represent symmetric or skewed unimodal responses. We assessed the effect of a truncated response curve along the local and European temperature gradients on the persistence coefficient by testing whether species with truncated response curves along the local and/or European climatic gradients had a persistence rate different from that of species without truncated response curves (Wilcoxon's signed-rank tests).

Finally, we assessed the difference in model evaluation (AUC) for each species between the local and European scales. The relationship between the species' local persistence and the difference in AUC was estimated by a linear regression.

\section{Results}

\section{Models performance}

Models obtained on average a fair evaluation at the local scale (mean $\mathrm{AUC}=0.84, \mathrm{SD}=0.08$ for species in the Diablerets, Appendix S1-a; and mean AUC $=0.81$,
Table 1 Percentage of species predicted to become extinct within $10 \times 10^{\prime}$ cells $(\mathrm{C} 1-\mathrm{C} 15)$ at the European scales (ES) under the four climate change scenarios

\begin{tabular}{llrrr}
\hline $10 \times 10^{\prime}$ cell & A1FI ES & A2 ES & B1 ES & B2 ES \\
\hline C1 & 76.2 & 38.1 & 19.0 & 26.2 \\
C2 & 61.9 & 26.2 & 9.5 & 23.8 \\
C3 & 42.9 & 16.7 & 11.9 & 14.3 \\
C4 & 83.3 & 47.6 & 31.0 & 28.6 \\
C5 & 38.1 & 16.7 & 11.9 & 11.9 \\
C6 & 38.1 & 16.7 & 11.9 & 14.3 \\
C7 & 64.3 & 28.6 & 16.7 & 11.9 \\
C8 & 38.1 & 11.9 & 11.9 & 14.3 \\
C9 & 35.7 & 11.9 & 7.1 & 9.5 \\
C10 & 52.3 & 6.8 & 13.6 & 4.5 \\
C11 & 54.2 & 10.4 & 12.5 & 6.3 \\
C12 & 40.5 & 2.4 & 11.9 & 2.4 \\
C13 & 52.2 & 10.9 & 15.2 & 6.5 \\
C14 & 45.5 & 2.3 & 13.6 & 2.3 \\
C15 & 54.2 & 12.5 & 18.8 & 8.3 \\
Mean & 51.8 & 17.3 & 14.4 & 12.3 \\
Standard deviation & 14.5 & 12.8 & 5.6 & 8.3 \\
\hline
\end{tabular}

$\mathrm{SD}=0.07$ for species in Zermatt, Appendix S1-b) and a good evaluation at the European scale (mean $\mathrm{AUC}=0.94, \mathrm{SD}=0.04$ for species in the Diablerets, Appendix S1-a; and mean $\mathrm{AUC}=0.96, \mathrm{SD}=0.04$ for species in Zermatt, Appendix S1-b), making them useful for deriving future projections.

\section{Predicted species loss at the European scale}

Predictions of species loss per $10 \times 10^{\prime}$ cells at the European scale (Table 1) are within the same order as those predicted previously (Bakkenes et al., 2002; Thuiller et al., 2005). Depending on which $10 \times 10^{\prime}$ cell is considered, maximum percent loss at the European scale was between $35.7 \%$ and $83.3 \%$ for the A1FI warming scenario and lowest rates between $2.3 \%$ and $28.6 \%$ for the B2 warming scenario (see also Supporting information Appendix S3).

\section{Local persistence rate and its potential causes}

Our results showed considerable variability in the temperature represented by $25 \mathrm{~m} \times 25 \mathrm{~m}$ cells within each $10 \times 10^{\prime}$ cell (Fig. 2). For all $10 \times 10^{\prime}$ cells, the temperature at the European scale reflects the mean conditions at the local scale. However, low-temperature regions that represent potential refuges for plants are not captured at the coarse resolution of the European-scale data.

Local habitat persistence coefficients were high, ranging between $69 \%$ (A1FI) and 74\% (B2) for the Diablerets area and $100 \%$ for the Zermatt area (Fig. 3; see also Supporting information Appendix S3). Difference in 
(a)

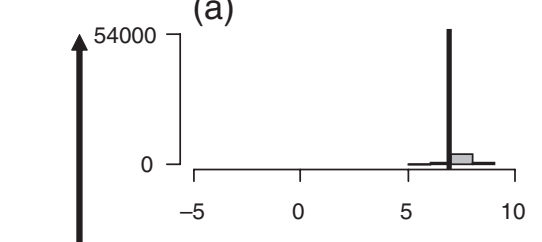

(d)

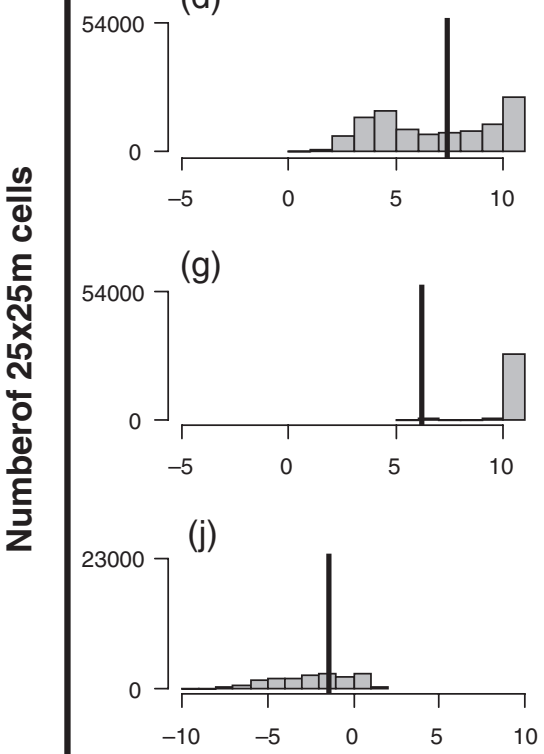

(m)

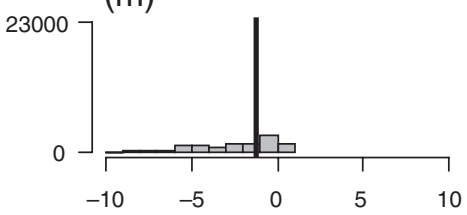

(b)

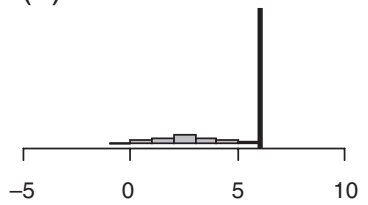

(e)

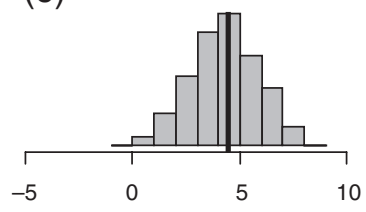

(h)

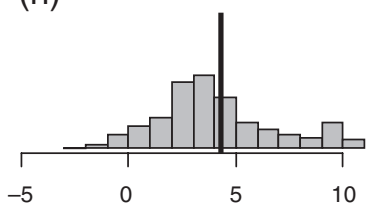

$(\mathrm{k})$

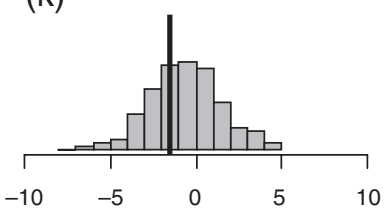

(n)

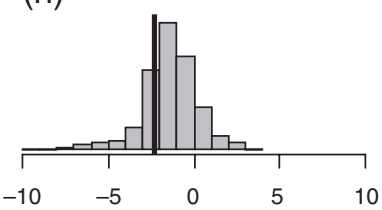

(c)

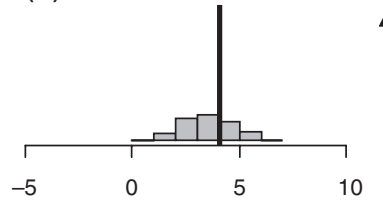

(f)

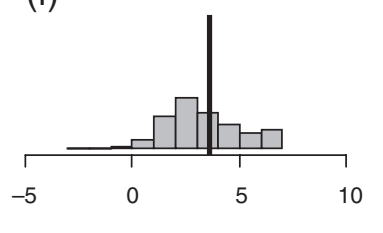

(i)

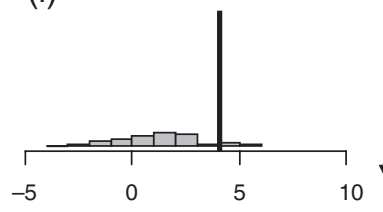

(l)

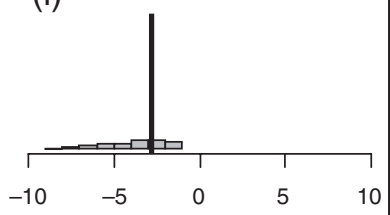

(o)

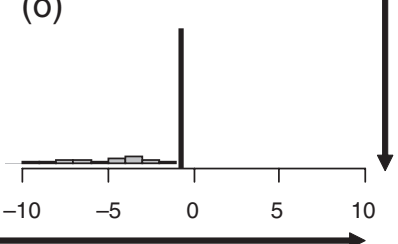

Temperature $\left({ }^{\circ} \mathrm{C}\right)$

Fig. 2 Frequency distribution of the mean annual temperature $\left(1^{\circ} \mathrm{C}\right.$ intervals $)$ for the $25 \mathrm{~m} \times 25 \mathrm{~m}$ cells within each $10 \times 10^{\prime}$ cell of Diablerets (a to i: D1 to D9) and Zermatt ( $\mathrm{j}$ to o: $\mathrm{Z1}$ to $\mathrm{Z6}$ ). The distribution of temperature reflects the local climatic variation within each $10 \times 10^{\prime}$ cell. The vertical lines indicate the mean annual temperature of $10 \times 10^{\prime}$ cells.

elevation range within $10 \times 10^{\prime}$ cells was correlated with predicted local persistence. We found a strong and significant relationship between persistence rate and elevation range within $10 \times 10^{\prime}$ cell under the four climate change scenarios (Fig. 4). The warmer the future climatic conditions, the higher the level of significance of the correlation. However, linear regressions showed no significant relationships between persistence rate and any other elevation attribute of $10 \times 10^{\prime}$ cells (surface, minimum, mean, and maximum elevation; all $P$-values $>0.05$ ). In addition, the rate of habitat persistence per elevation belt was in general high for species with optima in the subalpine and alpine zones in both study areas (Table 2) but was the highest overall in Zermatt.

Finally, no significant relationship $(P$-value $>0.05)$ was observed for any scenario between habitat persis- tence locally and any of the other factors tested: (i) difference in niche position, (ii) truncated response curves along temperature on one or both scales, (iii) model quality between the two scales, (iv) modeling techniques, and (v) model evaluation (AUC).

\section{Sensitivity analysis of the $\mathrm{P}$ coefficient}

When increasing the minimum number of remaining $25 \mathrm{~m} \times 25 \mathrm{~m}$ cells from 1 to 2000 , the $P$ coefficient decreased by $19.9 \%$ and $19.1 \%$ under A1 for Diablerets and Zermatt, respectively (Fig. 5; see also Supporting information Appendix S4). The decrease under B2 was $3.1 \%$ for Diablerets, whereas the $P$ coefficient remained stable in Zermatt. 
(a)

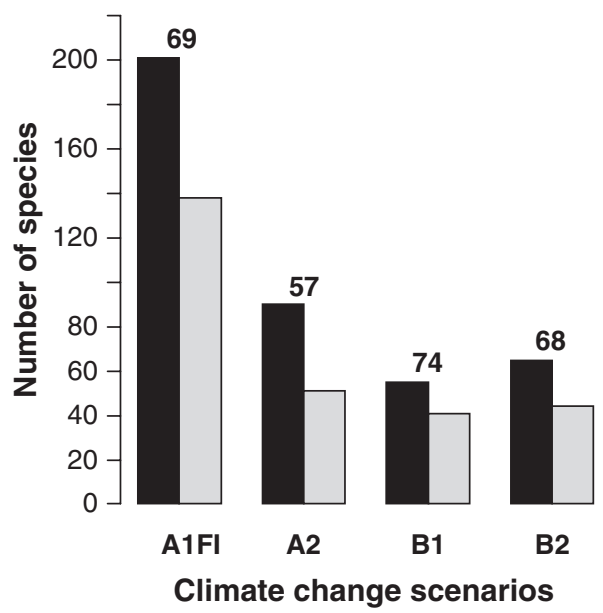

(b)

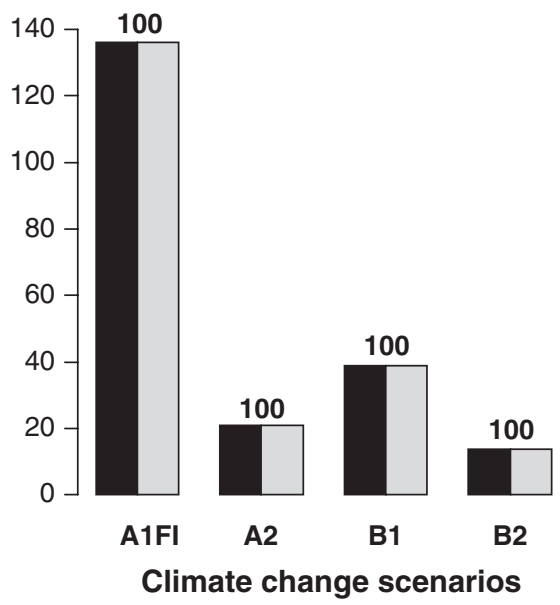

Fig. 3 Number of cases where a $10 \times 10^{\prime}$ cell becomes unsuitable for a species (black) compared with the number of cases where suitable habitat persists for these species in a $10 \times 10^{\prime}$ when modeled at the local ( $25 \mathrm{~m} \times 25 \mathrm{~m}$ cells) scale (gray) for Diablerets (a) and Zermatt (b). The local persistence coefficient is indicated on the top of each bar. All $10 \times 10^{\prime}$ cells in each study area are pooled.

(a)

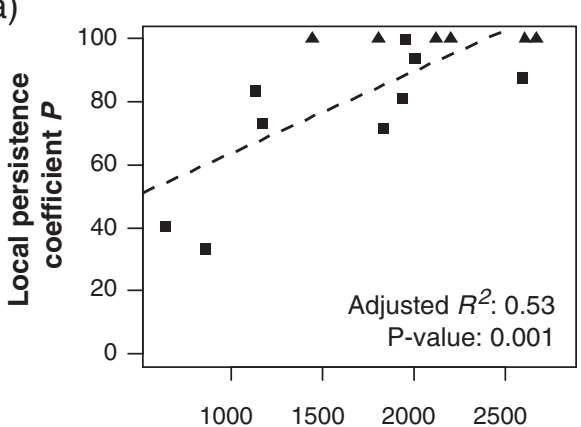

(c)

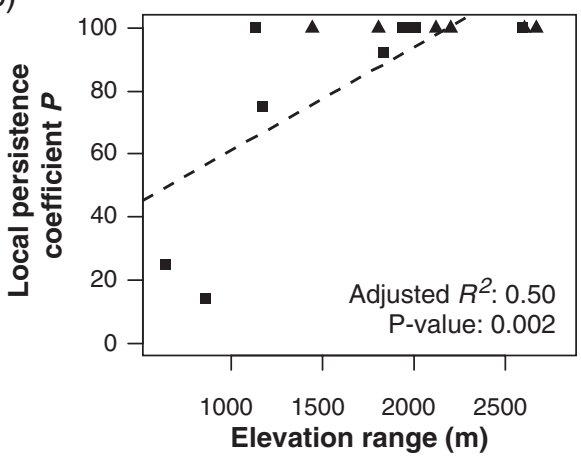

(b)

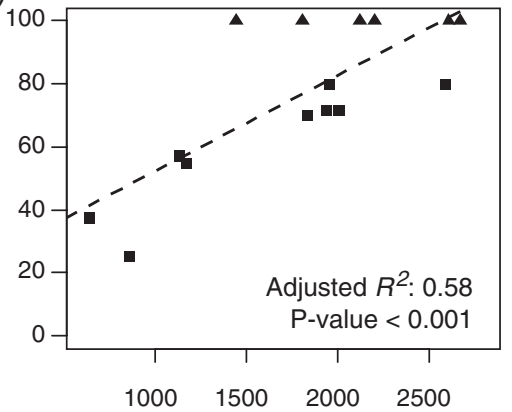

(d)

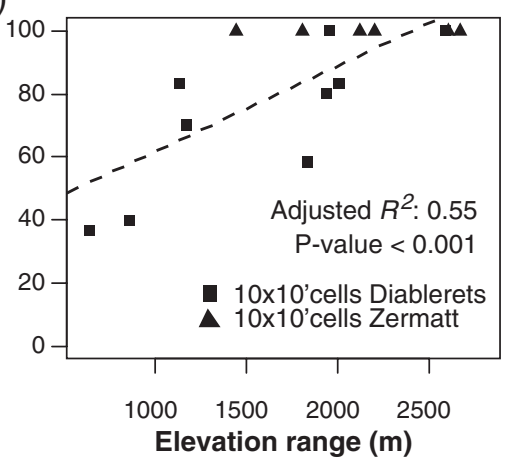

Fig. 4 Relationship between the local coefficient of persistence $P$ and the elevation range of $25 \mathrm{~m} \times 25 \mathrm{~m}$ cells within a $10 \times 10^{\prime}$ cell under the four climate change scenarios (a: A1FI, b: A2, c: B1, d: B2). The $P$ coefficient has been calculated for each $10 \times 10^{\prime}$ cell individually (cell-specific $P$ ). The dashed lines represent regression trends.

\section{Discussion}

In this study, we assessed the 'local high-elevation persistence hypothesis' for 78 mountain species modeled at both European and local scales. We found that local models predicted persistence of some habitat of a number of species in $10 \times 10^{\prime}$ cells that were predicted by models fitted at the European scale to contain no habitat. Persistence rates of habitat were especially high when considering the most severe warming scenario A1FI and were also greater in the Zermatt study area than in the Diablerets area owing to the presence of 
higher elevations in the Zermatt area. Finally, the divergence between scales remained of ca. $50 \%$ when considering a minimum surface of ca. $1 \mathrm{~km}^{2}$ for species to persist under the future climate conditions. Hence, our results give support to the persistence high-elevation habitat hypothesis, but too many limitations affecting the comparison between scales still prevent a formal testing of this hypothesis. Furthermore, it is impossible without data on future plant distributions to know if local projections are better than global ones.

Overall, we observed a strong relationship between the proportion of species with persisting habitat and the

Table 2 Persistence coefficient $(P)$ per optimum of elevation

\begin{tabular}{lrlllll}
\hline & \multicolumn{2}{c}{ Diablerets } & & & \multicolumn{2}{l}{ Zermatt } \\
\cline { 2 - 3 } \cline { 7 - 8 } & M & S & A & & S & A \\
\hline A1FI & 100 & 68 & 61 & & 100 & 100 \\
A2 & 68 & 73 & 17 & 100 & 100 \\
B1 & 100 & 78 & 50 & 100 & 100 \\
B2 & 77 & 81 & 23 & & 100 & 100 \\
\hline
\end{tabular}

The climate change scenarios are represented for each study area and $10 \times 10^{\prime}$ cells in each study area are pooled (cellspecific $P$ ).

M, montane; S, subalpine; A, alpine.
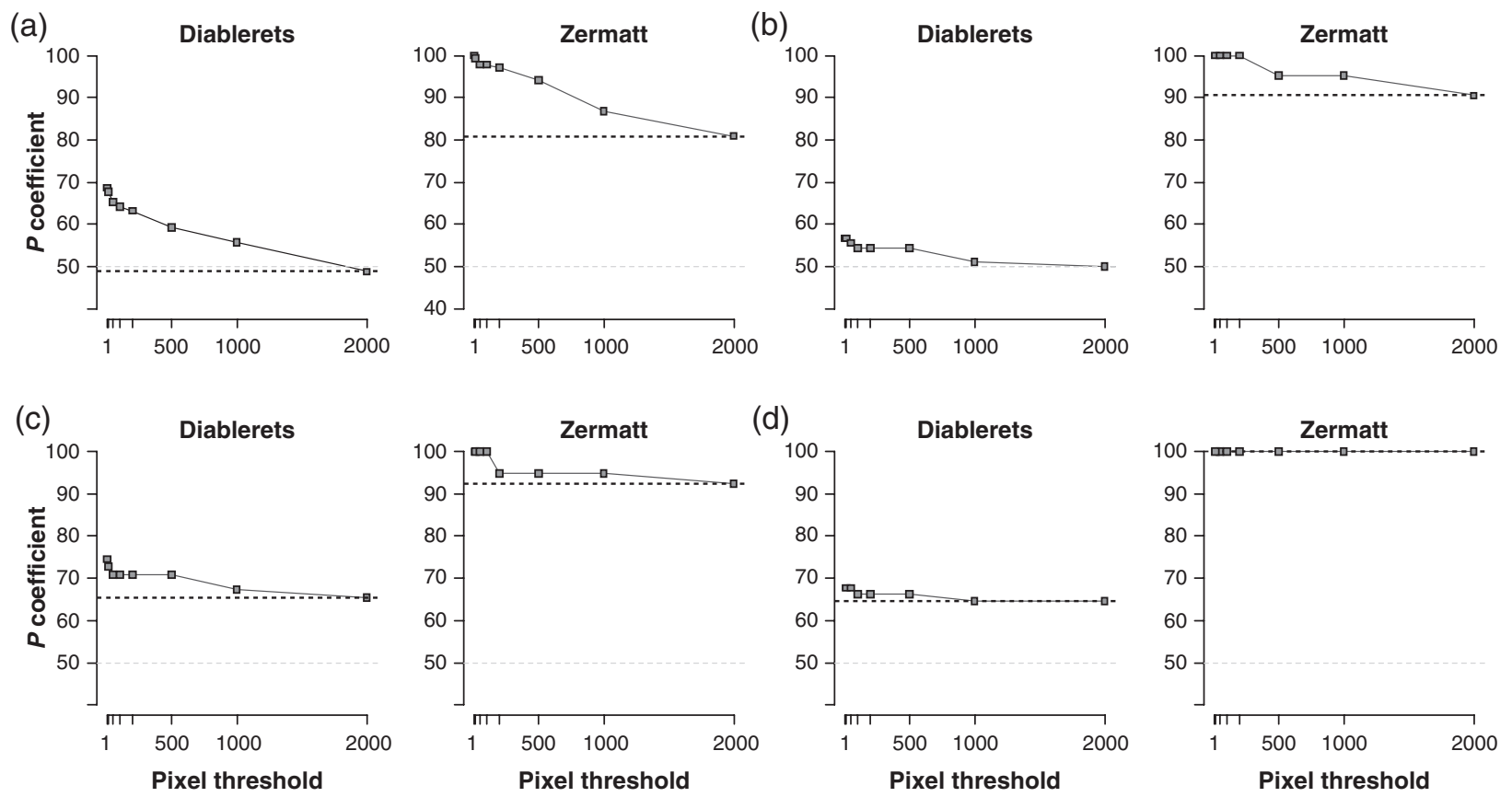

observed elevation range calculated from fine-grained data within $10 \times 10^{\prime}$ cells. Greater habitat persistence also occurred in alpine species in Zermatt than in the Diablerets, suggesting that elevation range is the main driver for the predicted local-scale habitat persistence. None of the other relationships we explored showed a significant relationship with the proportion of species with persisting habitat.

Our results highlight the importance of assessing the potential impacts of climate change on species distributions at several scales, especially at local scale in mountain areas where the rugged topography requires fine mapping of environmental predictors. Possible highelevation refuges for alpine and nival plants are likely better captured at a $25 \mathrm{~m} \times 25 \mathrm{~m}$ resolution than at a $10 \times 10^{\prime}$ resolution, as the latter corresponds to $16 \mathrm{~km} \times 16 \mathrm{~km}$ cells in the Swiss Alps. This contrast between scales might help to explain the quaternary conundrum, i.e. why fewer species than expected went extinct during glacial periods when models predict so many extinctions with similar amplitude of climate change (Botkin et al., 2007).

However, local predictions are also entailed with a major weakness compared with predictions at the extent of Europe: the full realized niche of species may be captured incompletely at local scale owing to the limited geographic - and therefore environmental - extent
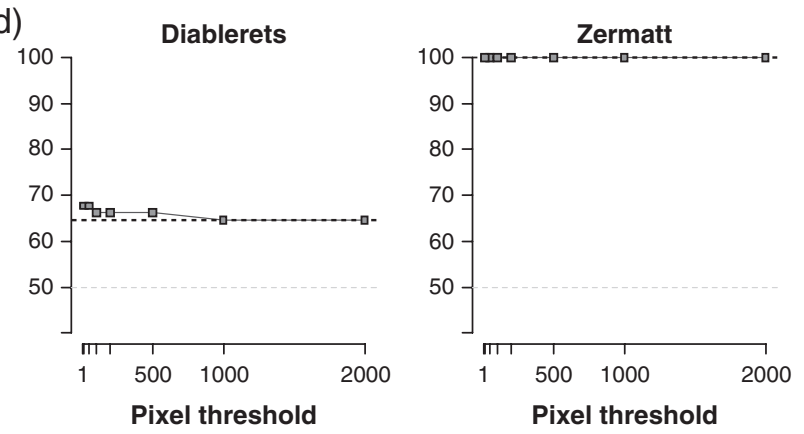

Fig. 5 Habitat persistence coefficient $(P)$ calculated as the number of $25 \mathrm{~m} \times 25 \mathrm{~m}$ cells with suitable habitat remaining for each species $(1,10,50,100,200,500,1000$, and $200025 \mathrm{~m} \times 25 \mathrm{~m}$ cells) for each climate change scenario (a: A1FI, b: A2, c: B1 and d: B2) and for Diablerets and Zermatt (cell-specific $P$ grouped by study area). The red dotted horizontal line represents the value of $P$ when calculated with a minimum number of $25 \mathrm{~m} \times 25 \mathrm{~m}$ cells necessary for a species to persist set to 2000 , and the gray dotted horizontal line represents a $P$ of 50 (50\% of divergence between scales). 
considered. In this case, truncated response curves may result for some species (especially low-elevation ones), and contribute to spurious predictions of future species distributions. If no distribution limit is established at both ends of the temperature gradient, species could potentially be predicted to either migrate indefinitely to higher elevations or remain present at the lowest elevation, even under climate change (Van Horn, 2002; Thuiller et al., 2004). Indeed, although we did not observe any relationship between truncation of these curves and habitat persistence in our study, truncation can have effects on projections of species future distributions (e.g. Thuiller et al., 2004) and thus deserves further investigation.

Some further limitations are also associated with local models. In our study, the set of local predictor variables may have not covered the full range of ecological requirements of the species, because it did not include process-based geomorphic predictors such as snow accumulation, rockfall, avalanche paths, or human-induced perturbations such as land use practices, which further contribute to limit species distributions (Dirnböck et al., 2003; Dirnbock \& Dullinger, 2004). However, we did not consider the retreat of glaciers in Zermatt, which in turn could contribute to increase available space for highelevation species, and thus to further increase the divergence between scales. Absences may also not be comparable between the two scales. At local scale, absences may be due to a number of nonclimate-related factors, such as competitive exclusion, demographic processes, or environmental stochasticity, whereas climate is more likely to drive absences at the European scale.

Overall, the main reason for habitat persistence under the local scenario seems to be the importance of the length of elevation gradient, and probably the associated local topographic diversity, expressed within each large $10 \times 10^{\prime}$ cell. Climatic differences along elevation gradients, as apparent at $25 \mathrm{~m} \times 25 \mathrm{~m}$ resolution (Fig. 2; see also Supporting information Appendix S2), allow plant species to find suitable climatic conditions at higher elevation under climate change. In contrast, models at a $10 \times 10^{\prime}$ resolution reflect the mean climatic conditions within the cell, and thus provide imprecise values of the probability of occurrence of species along a thermal gradient. Global circulation models, from which some European-scale predictors were derived, likely do not express hygric continentality from the precipitation regime. This is suggested by precipitation being over- or underestimated in both study areas (results not shown, see Supporting information Appendix S2), thus contributing to the discrepancies between predictions at the two scales.

Continentality is an important climatic driver in mountain systems (Beniston, 2006). Inaccurate estima- tion of it by global or regional circulation models will hamper the prediction of species distributions in response to climate change. As highlighted by NoguésBravo et al. (2006), the coarse spatial resolution of GCMs/ RCMs used at the European scale does not enable to capture the complex, topographically driven spatial patterning of temperature and other regional climate features at local scale. We thus propose a combination of GCM/RCM anomaly mapping downscaled and combined with finer scale present day climate maps, in order to better reflect local patterns of climate change within individual mountain ranges. Subalpine and alpine species in Zermatt were predicted to be less threatened by climate change - and thus show a higher persistence rate - than in the Diablerets. This result further highlights the importance of assessing the impact of climate change locally and independently for distinct mountain regions.

Local persistence may also result in local adaptations of species regarding their environment (e.g. ecotypes) and to local changes in biotic interactions that may result in changes of a species' realized niche. This may affect comparisons between European- and localscale models and projections (Randin et al., 2006).

Several new developments may contribute to the improvement of local models. First, our predictions were made assuming unlimited dispersal from present to future conditions found at higher elevations. Considering dynamic dispersal as climate changes progressively - and possibly nonlinearly over time - is an important constraint that needs to be added to static projections from SDMs (Thuiller et al., 2008). So far, such examples only exist for few species (Carey, 1996; Dullinger et al., 2004).

Second, the set of climatic predictors used in our study may be further improved to better express the true habitat requirements of species. Although our set of predictors was chosen to reflect as much as possible the known physiological requirements of species, deriving even more proximal predictors would allow a finer and ecologically more meaningful characterization of the species' realized niche (Guisan \& Zimmermann, 2000; Austin, 2002). This should improve local projections of future species' distributions (Guisan \& Thuiller, 2005).

Third, improved projections are likely to be obtained by combining the strength of models fitted at the two scales, by fitting the full realized climatic niche of a species from large-scale data picturing the whole species' range (e.g. AFE data at the European scale), and then refining the part of the niche where projections have to be made with finer scale data and local predictors. Such hierarchical approach of environmental drivers of species distributions (Pearson \& Dawson, 2004) is worth further development and should be specifically tested for deriving improved projections of 
future species distributions. Models could also be improved by considering additional techniques in an ensemble modeling approach (Araujo \& New, 2007), like random forest (Prasad et al., 2006), support vector machine (Drake et al., 2006) or maxent (Phillips et al., 2006), which showed promising results in other modeling studies of species distribution.

Fourth and the last, the rough projections obtained from niche-based models could be used in conducting PVA for species in the study areas. Currently, this step cannot be made because we lack an adequate procedure to estimate extinction risks from the area predicted to remain suitable for a species under future climatic conditions (Botkin et al., 2007). In this study, we considered that a species could persist at the local scale if only one $25 \mathrm{~m} \times 25 \mathrm{~m}$ cell persisted. Long-term persistence of species in only one such cell is ecologically questionable. However, even when considering a minimum viable surface of more than $1 \mathrm{~km}^{2}$ for persistence (i.e. $200025 \mathrm{~m} \times 25 \mathrm{~m}$ cells), the habitat persistence coefficient remained large (i.e. over $50 \%$; see Supporting information Appendix S4). Adding a PVA requires, at least, information on (i) the degree of occupancy of suitable habitat by each species under current condition, (ii) the degree of contiguity of the remaining habitat, and (iii) the minimum absolute number of suitable cells a species requires to maintain positive population growth. This is a challenging, yet feasible, task (Morris \& Doak, 2003).

Interestingly, a recent cross-scale comparison study found results opposite to ours (Trivedi et al., 2008). Projections of European-scale model $(50 \mathrm{~km} \times 50 \mathrm{~km})$ predicted the persistence of 10 species in a mountain range of Scotland, while local models $(50 \mathrm{~m} \times 50 \mathrm{~m})$ predicted the extinction of nine of them. The authors discuss that European models overestimated species' thermal tolerances, because the input coarse-resolution climate data were biased against the cold, high-altitude habitats of mountain plants. Further studies are thus required to assess, across a larger number of mountain ranges, whether local predictions over- or underpredict species extinctions compared with large-scale projections.

\section{Conclusion}

Our study yielded two main conclusions. First, localscale models can predict persistent species habitat at high elevations within large cells that are predicted by coarse-resolution, European-scale models to become unsuitable (the 'local high-elevation refuge hypothesis'). Hence, European-wide projections might overestimate extinction risks for alpine species. Yet, for some species, local habitat persistence often owed to very few suitable $25 \mathrm{~m} \times 25 \mathrm{~m}$ cells, suggesting a tenuous connec- tion of habitat persistence with species persistence. Thus, for these species, predictions based on the European-scale data and resolutions remain plausible. These results require further testing. Secondly, models fitted at both scales examined here have strengths and drawbacks. In future studies, we suggest combining their strengths in a hierarchical approach that can estimate the full realized climatic niche of species while benefiting from finer environmental predictors locally.

\section{Acknowledgements}

This study was supported by the Centre de Conservation de la Nature (SFFN) of the Canton de Vaud, the Swiss National Science Foundation (SNF Grant No. 3100A0-110000), and the European Science Commission (FP6 projects ECOCHANGE and MACIS). We thank all the people who helped in the field, particularly Stéfanie Maire, Dario Martinoni, Séverine Widler, Chantal Peverelli, Valentine Hof, Grégoire Vuissoz, Lorenzo De Stefani, Roxane Milleret, Pierre Bermane Favrod-Coune, Daniel Cherix, Anny. and Willy Berra. C.R. and A.G. greatly benefited from the interactions with colleagues within the Swiss National Centre for Competence in Research (NCCR) 'Plant survival in natural and agricultural ecosystems' (http://www.unine.ch/ nccr). We are particularly grateful to Dr Stefan Dullinger for his useful comments during the revision.

\section{References}

Aeschimann D, Heitz C (1996) Index Synonymique de la Flore de Suisse et Territoires Limitrophes. CRSF, Genève, Switzerland.

Aeschimann D, Lauber K, Moser DM et al. (2005) Flora Alpina. Belin, Paris, France.

Araujo MB, Guisan A (2006) Five (or so) challenges for species distribution modelling. Journal of Biogeography, 33, 1677-1688.

Araujo MB, New M (2007) Ensemble forecasting of species distributions. Trends in Ecology and Evolution, 22, 42-47.

Araujo MB, Thuiller W, Williams PH, Reginster I (2005a) Downscaling European species atlas distributions to a finer resolution: implications for conservation planning. Global Ecology and Biogeography, 14, 17-30.

Araujo MB, Whittaker RJ, Ladle RJ, Erhard M (2005b) Reducing uncertainty in projections of extinction risk from climate change. Global Ecology and Biogeography, 14, 529-538.

Austin MP (2002) Case studies of the use of environmental gradients in vegetation and fauna modelling: theory and practice in Australia and New Zealand. In: Predicting Species Occurrences: Issues of Accuracy and Scale (eds Scott JM, Heglund PJ, Samson F, Haufler J, Morrison M, Raphael M, Wall B), pp. 73-82. Island Press, Covelo, CA, USA.

Bahn M, Körner C (2003) Recent increase in summit flora caused by warming in the Alps. In: Alpine Biodiversity in Europe (eds Nagy L, Grabherr G, Körner C, Thompson DBA), pp. 437-441. Springer, Berlin, Germany.

Bakkenes M, Alkemade JRM, Ihle F, Leemans R, Latour JB (2002) Assessing effects of forecasted climate change on the diversity and distribution of European higher plants for 2050. Global Change Biology, 8, 390-407. 
Beniston M (2006) Mountain weather and climate: a general overview and a focus on climatic change in the Alps. Hydrobiologia, 562, 3-16.

Beniston M, Fox DG, Adhikary S et al. (1996) Impacts of climate change on mountain regions. In: Intergovernmental Panel on Climate Change. Second Assessment Report (ed. IPCC). pp. 191213. Cambridge University Press, Cambridge, UK.

Botkin DB, Saxe H, Araujo MB et al. (2007) Forecasting the effects of global warming on biodiversity. Bioscience, 57, 227-236.

Bouët M (1985) Climat et météorologie de la Suisse romande. Payot, Lausanne, Switzerland.

Braun-Blanquet J (1957) Ein Jahrhunder Florenwandel am Piz Linard (3414 m). Bulletin du Jardin Botanique de l'Etat a Bruxelles, volume jubilaire Walter Robyns, 221-232.

Broennimann O, Treier UA, Muller-Scharer H, Thuiller W, Peterson AT, Guisan A (2007) Evidence of climatic niche shift during biological invasion. Ecology Letters, 10, 701-709.

Carey PD (1996) DISPERSE: a cellular automaton for predicting the distribution of species in a changed climate. Global Ecology and Biogeography Letters, 5, 217-226.

Carson DJ (1999) Climate modelling: achievements and prospects. Quarterly Journal of the Royal Meteorological Society, 125, 1-27.

Davis AJ, Jenkinson LS, Lawton JH, Shorrocks B, Wood S (1998) Making mistakes when predicting shifts in species range in response to global warming. Nature, 391, 783-786.

Diaz HF, Grosjean M, Graumlich L (2003) Climate variability and change in high elevation regions: past, present and future. Climatic Change, 59, 1-4.

Dirnbock T, Dullinger S (2004) Habitat distribution models, spatial autocorrelation, functional traits and dispersal capacity of alpine plant species. Journal of Vegetation Science, 15, 77-84.

Dirnböck T, Dullinger S, Grabherr G (2003) A regional impact assessment of climate and land-use change on alpine vegetation. Journal of Biogeography, 30, 401-417.

Dormann CF (2007) Promising the future? Global change projections of species distributions. Basic and Applied Ecology, 8, 387397.

Drake JM, Randin C, Guisan A (2006) Modelling ecological niches with support vector machines. Journal of Applied Ecology, 43, 424-432.

Dullinger S, Dirnbock T, Grabherr G (2004) Modelling climate change-driven treeline shifts: relative effects of temperature increase, dispersal and invasibility. Journal of Ecology, 92, 241-252.

Elith J, Graham CH, Anderson RP et al. (2006) Novel methods improve prediction of species' distributions from occurrence data. Ecology, 29, 129-151.

Fielding AH, Bell JF (1997) A review of methods for the assessment of prediction errors in conservation presence-absence models. Environmental Conservation, 24, 38-49.

Frescino TS, Edwards TC, Moisen GG (2001) Modeling spatially explicit forest structural attributes using generalized additive models. Journal of Vegetation Science, 12, 15-26.

Friedman JH, Hastie T, Tibshirani R (2000) Additive logistic regression: a statistical view of boosting. Annals of Statistics, 28, 337-374.

Gehrig-Fasel J (2007) Treeline and climate change: analyzing and modeling patterns and shifts in the Swiss Alps. PhD thesis, Université de Lausanne, Lausanne, 132 pp.
Grabherr G, Gottfried M, Pauli H (1994) Climate effects on mountain plants. Nature, 369, 448.

Guisan A, Edwards TC, Hastie T (2002) Generalized linear and generalized additive models in studies of species distributions: setting the scene. Ecological Modelling, 157, 89-100.

Guisan A, Holten JI, Spichiger R et al., (eds) (1995) Potential Ecological Impacts of Climate Change in the Alps and Fennoscandian Mountains. Conservatoire et Jardin Botaniques, Geneva, Switzerland.

Guisan A, Theurillat J-P (2000) Assessing alpine plant vulnerability to climate change: a modeling perspective. Integrated Assessment, 1, 307-320.

Guisan A, Thuiller W (2005) Predicting species distribution: offering more than simple habitat models. Ecology Letters, 8, 993-1009.

Guisan A, Zimmermann NE (2000) Predictive habitat distribution models in ecology. Ecological Modelling, 135, 147-186.

Gurtz J, Baltensweiler A, Lang H (1999) Spatially distributed hydrotope-based modelling of evapotranspiration and runoff in mountain basins. Hydrological Processes, 13, 2751-2768.

Hampe A (2004) Bioclimate envelope models: what they detect and what they hide. Global Ecology and Biogeography, 13, 469-476.

Hill MF, Caswell H (1999) Habitat fragmentation and extinction threshold on fractal landscapes. Ecology Letters, 2, 121-127.

Hofer HR (1992) Veränderungen in der Vegetation von 14 Gipfeln der Berninagebietes zwischen 1905 und 1985. Berichte des Geobotanischen Institutes der Eidgenössischen Technischen Hochschule Stiftung Rübel Zürich, 58, 39-54.

Huisman J, Olff H, Fresco LFM (1993) A hierarchical set of models for species response analysis. Journal of Vegetation Science, 4, 37-46.

Hutchinson GE (1957) Population studies - animal ecology and demography - concluding remarks. Cold Spring Harbor Symposia on Quantitative Biology, 22, 415-427.

Kearney M, Porter WP (2004) Mapping the fundamental niche: physiology, climate, and the distribution of a nocturnal lizard. Ecology, 85, 3119-3131.

Körner C (2003) Alpine Plant Life, 2nd edn. Springer, Berlin, Germany.

Lahti T, Lampinen R (1999) From dot maps to bitmaps - Atlas Flora Europaeae goes digital. Acta Botanica Fennica, 162.

Leathwick JR, Elith J, Francis MP, Hastie T, Taylor P (2006) Variation in demersal fish species richness in the oceans surrounding New Zealand: an analysis using boosted regression trees. Marine Ecology - Progress Series, 321, 267-281.

Morris WF, Doak DF (2003) Quantitative Conservation Biology: Theory and Practice of Population Viability Analysis. Sinauer Associates, Sunderland, MA, USA.

Nakicenovic N, Swart R (eds) (2000) Emissions Scenarios: A Special Report of Working Group III of the Intergovernmental Panel on Climate Change. Cambridge University Press, Cambridge, UK.

Nogués-Bravo D, Araújo MB, Martinez-Rica JP, Errea MP (2006) Exposure of global mountain systems to climate warming during the 21st century. Global Environmental Change, 17, $420-428$

Oksanen J, Minchin PR (2002) Continuum theory revisited: what shape are species responses along ecological gradients? Ecological Modelling, 157, 119-129. 
Pauli H, Gottfried M, Grabbherr G (1996) Effects of climate change on mountain ecosystems. Upward shifting of alpine plants. World Resource Review, 8, 382-390.

Pauli H, Gottfried M, Reiter K, Klettner C, Grabherr G (2007) Signals of range expansions and contractions of vascular plants in the high Alps: observations (1994-2004) at the GLROIA master site Schrankogel, Tyrol, Austria. Global Change Biology, 13, 147-156.

Pearce J, Ferrier S (2000) An evaluation of alternative algorithms for fitting species distribution models using logistic regression. Ecological Modelling, 128, 127-147.

Pearman P, Van der Knaap P, Randin CR et al. (2008) Prediction of plant species distributions across six millennia. Ecology Letters, 11, 357-369.

Pearson D, Dawson TP (2004) Modelling species distribution in Britain: a hierarchical integration of climate and land-cover data. Ecography, 27, 285-298.

Phillips SJ, Anderson RP, Schapire RE (2006) Maximum entropy modeling of species geographic distributions. Ecological Modelling, 190, 231-259.

Prasad AM, Iverson LR, Liaw A (2006) Newer classification and regression tree techniques: bagging and random forests for ecological prediction. Ecosystems, 9, 181-199.

Prentice C, Cramer W, Harrison SP, Leemans R, Monserud RA, Solomon AM (1992) A global biome model based on plant physiology and dominance, soil properties and climate. Journal of Biogeography, 19, 117-134.

Randin CF, Dirnbock T, Dullinger S, Zimmermann NE, Zappa M, Guisan A (2006) Are niche-based species distribution models transferable in space? Journal of Biogeography, 33, 1689-1703.

Theurillat J-P, Felber F, Geissler P et al. (1998) Sensitivity of plant and soil ecosystems of the Alps to climate change. In: Views from the Alps. Regional Perspectives on Climate Change (eds Cebon P, Dahinden U, Davies HC, Imboden D, Jäger CC), pp. 225-308. MIT Press, London, UK.

Thomas CD, Cameron A, Green RE et al. (2004) Extinction risk from climate change. Nature, 427, 145-147.

Thuiller W (2003) BIOMOD - optimizing predictions of species distributions and projecting potential future shifts under global change. Global Change Biology, 9, 1353-1362.

Thuiller W, Albert C, Araújo MB et al. (2008) Predicting global change impacts on plant species distributions: where to go from here? Perspectives in Plant Ecology, Evolution and Systematics, 9, 137-152.

Thuiller W, Broennimann O, Hughes G, Alkemade JRM, Midgley GF, Corsi F (2006a) Vulnerability of African mammals to anthropogenic climate change under conservative land transformation assumptions. Global Change Biology, 12, 424-440.

Thuiller W, Brotons L, Araujo MB, Lovorel (2004) Effects of restricting environmental range of data to project current and future species distributions. Ecography, 27, 165-172.

Thuiller W, Lavorel S, Araujo MB, Sykes MT, Prentice IC (2005) Climate change threats to plant diversity in Europe. Proceedings of the National Academy of Sciences of the United States of America, 102, 8245-8250.

Thuiller W, Midgley GF, Rouget M, Cowling RM (2006b) Predicting patterns of plant species richness in megadiverse South Africa. Ecography, 29, 733-744.
Trivedi MR, Berry PM, Morecroft MD, Dawson TP (2008) Spatial scale affects bioclimate model projections of climate change impacts on mountain plants. Global Change Biology, 14, 1089-1103.

Van Horn B (2002) Approaches to habitat modelling: the tensions between pattern and process and between specificity and generality. In: Predicting Species Occurrences: Issues of Accuracy and Scale (eds Scott JM, Heglund PJ, Morrison ML et al.), pp. 63-72. Island Press, Covelo, CA, USA.

Vittoz P, Jutzeler S, Guisan A (2006) Flore alpine et réchauffement climatique: observation de trois sommets valaisans à travers le 20ème siècle. Bulletin de la Murithienne, 123/2005, 49-59.

Walther G-R (2003) Plants in a warmer world. Perspectives in Plant Ecology, Evolution and Systematics, 6, 169-185.

Walther G-R, Beißner S, Burga CA (2005) Trends in the upward shift of alpine plants. Journal of Vegetation Science, 16, 541-548.

Yee TW, Mitchell ND (1991) Generalized additive models in plant ecology. Journal of Vegetation Science, 2, 587-602.

Zimmermann NE, Kienast F (1999) Predictive mapping of alpine grasslands in Switzerland: species versus community approach. Journal of Vegetation Science, 10, 469-482.

\section{Supporting Information}

Additional Supporting Information may be found in the online version of this article:

Appendix S1. Species found in either (a) the Diablerets or (b) Zermatt dataset and are in the Atlas Florae Europaeae (AFE). The best modeling technique used for spatial projection and its area under the curve (AUC) value are indicated for each species and each scale. The elevation index (EI) is the last column. See separated Excel files for (a) the Diablerets and (b) Zermatt.

Appendix S2. Relationships between (a) projections of the mean annual temperature at the local scale ( $x$-axis) and within the $10 \times 10^{\prime}$ cells at the European scale (y-axis) and (b) projections of the mean annual precipitation at the local scale ( $x$-axis) and within the $10 \times 10^{\prime}$ cells at the European scale (y-axis). The mean temperature and mean precipitation at the local scale are calculated by averaging the values of all $25 \mathrm{~m} \times 25 \mathrm{~m}$ cells of one of the study areas within a $10 \times 10^{\prime}$ cell. The diagonal represents a perfect agreement between scales and the dashed lines are regressions lines.

Appendix S3. Number of $25 \mathrm{~m} \times 25 \mathrm{~m}$ (LS) and $10 \times 10^{\prime}$ (ES) cells remaining for each species under the four climate change scenarios for (a) the Diablerets (D1 to D9) and (b) Zermatt (Z1 to Z6). See separated Excel files for (a) the Diablerets and (b) Zermatt. Appendix S4. Habitat persistence coefficient $(P)$ calculated as the number of $25 \mathrm{~m} \times 25 \mathrm{~m}$ cells with suitable habitat remaining for each species $(1,10,50,100,200,500,1000$, and 2000 $25 \mathrm{~m} \times 25 \mathrm{~m}$ cells) for each climate change scenario.

Please note: Wiley-Blackwell are not responsible for the content or functionality of any supporting materials supplied by the authors. Any queries (other than missing material) should be directed to the corresponding author for the article. 